\title{
Proteomic analysis of the excretory-secretory proteins of the Trichinella spiralis L1 larva, a nematode parasite of skeletal muscle
}

\section{Mark W. Robinson and Bernadette Connolly}

School of Medical Sciences, Institute of Medical Sciences, University of Aberdeen, Aberdeen AB25 2ZD, Scotland, UK

Running title: Excretory-secretory proteins of the Trichinella spiralis muscle larva

Correspondence: Dr Bernadette Connolly, School of Medical Sciences, Institute of Medical Sciences, University of Aberdeen, Aberdeen AB25 2ZD, Scotland, UK

Email: b.connolly@abdn.ac.uk

Telephone: +44 1224 555825; Fax: +44 1224 555844;

Abbreviations: ES, excretory-secretory

Keywords: nematode/Trichinella/muscle larva/MALDI-TOF/ Tandem Mass Spectrometry 


\begin{abstract}
Trichinella spiralis is an intracellular nematode parasite of mammalian skeletal muscle. Infection of the muscle cell leads to the formation of a host-parasite complex that results in profound alterations to the host cell and a re-alignment of muscle-specific gene expression. The role of parasite excretory-secretory (ES) proteins in mediating these effects is currently unknown, largely due to the difficulty in identifying and assigning function to individual proteins. In this study, a global proteomics approach was used to analyse the ES proteins from $T$. spiralis muscle larvae. Following 2-dimensional electrophoresis (2-DE) of ES proteins, matrix-assisted laser desorption/ionization-time of flight (MALDI-TOF)mass spectrometry and liquid chromatography tandem mass spectrometry (LCMS/MS) were used to identify the peptide spots. Specific Trichinella EST databases were assembled and used to analyse the data. Despite the current absence of a Trichinella genome-sequencing project, 43 out of 52 protein spots analysed were identified and included the major secreted glycoproteins. Other novel proteins were identified from matches with sequences in the $T$. spiralis database. Our results demonstrate the value of proteomics as a tool for the identification of Trichinella ES proteins and in the study of the molecular mechanism underpinning the formation of the host-parasite complex during Trichinella infections.
\end{abstract}




\section{Introduction}

Profound alterations in skeletal muscle can occur as a result of injury, disease or infection with pathogens. One of the most extreme cases is observed in cells infected with the nematode parasite, Trichinella spiralis, an intracellular parasite specific for mammalian skeletal muscle. The newborn L1 larva migrates from the intestine of the host to the skeletal muscle where it infects and encapsulates within a portion of the myofiber and develops into the infective or muscle L1 larva [1]. During this process an intimate host-parasite complex, the nurse cell, is formed. Infection of the terminally-differentiated cell by $T$. spiralis leads to profound changes, including re-entry into the cell cycle with subsequent suspension at the G2/M border, down-regulation of muscle-specific gene [2] and muscle-specific protein [3] expression, dissolution of myofibrils, proliferation of secretory organelles and nuclear enlargement [4]. These changes to the infected muscle cell suggest that the differentiated state in the skeletal muscle cell is repressed and that post-infection a process of de-differentiation is initiated. This is followed by re-differentiation into an alternative cell type, one that is adapted to support the parasite until its transmission to the next host. The molecular mechanisms underlying the re-programming of the skeletal muscle are currently unknown although there is circumstantial evidence implicates larval excretorysecretory (ES) proteins in the formation and/or maintenance of the nurse cell. ES proteins collected from both newborn larvae and muscle larvae elicit morphological and structural changes to cultured primary rat myocytes [5]. 
Furthermore, antigens sharing epitopes with secreted Trichinella proteins have been detected within isolated host cell nuclei where they co-localise with nuclear chromatin complexes $[6,7,8]$. However, the abundance of these proteins has been too low to allow identification and therefore confirmation of the parasite origin of these antigens awaits data connecting them to Trichinella-encoded genes. Although several biochemical activities have been observed in the Trichinella ES fraction, including DNA-binding [9], DNA endonuclease [10, $11]$, protease $[12,13]$ and kinase activities $[14,15]$, relatively few of the proteins responsible or the genes encoding them have been characterised to date.

The identification and characterisation of ES proteins is of fundamental importance to understanding the mechanism of parasite-induced dedifferentiation. Recently, mass spectrometric analysis has led to the identification of two ES proteins, a $67 \mathrm{kDa}$ 5'-nucleotidase [16] and a putative serine protease [17]. This suggests that the application of proteomics may circumvent many of the problems encountered with the identification of ES proteins in the past. Proteomic analysis has been successfully used to identify ES proteins from other helminth parasites such as the nematode Haemonchus contortus [18] and the trematode Fasciola hepatica $[19,20]$. In the current study, we have used data collected from 2-DE and mass spectrometry (MS) to analyse and identify the ES proteins from $T$. spiralis muscle larvae. This represents the first study which attempts to comprehensively identify Trichinella ES proteins and, as such, will provide valuable information for further studies. 


\section{Materials \& Methods}

\subsection{Parasites}

T. spiralis (ISS390) parasites were maintained in female ICR/CD1 mice and muscle larvae were isolated from infected mice as previously described [21].

\subsection{Collection and preparation of ES proteins}

Isolated $T$. spiralis muscle larvae were washed several times in pre-warmed RPMI 1640 medium (Invitrogen) and resuspended at 5000 muscle larvae $\mathrm{ml}^{-1}$ in RPMI containing $2 \mathrm{mM}$ L-glutamine, $100 \mathrm{U} \mathrm{ml}^{-1}$ penicillin, $100 \mu \mathrm{g} \mathrm{ml}^{-1}$ streptomycin. The parasites were maintained at $37^{\circ} \mathrm{C} / 5 \% \mathrm{CO}_{2}$ for up to $20 \mathrm{~h}$ after which the larvae were allowed to sediment and the culture medium containing the ES protein was collected [22]. Where necessary, the larvae were resuspended in fresh culture medium and incubated for a further $20 \mathrm{~h}$ under the same conditions. ES proteins were concentrated from the culture supernatants by precipitation with methanol / chloroform [23]. Normally, $400 \mu \mathrm{l}$ of culture supernatant was used for 1-DE and $1.6 \mathrm{ml}$ for 2-DE, although volumes were adjusted to ensure equal loading between successive gels. Protein samples were resuspended in buffer (100 mM Tris-HCl, pH 6.8, 200 mM DTT, 4\% SDS, 20\% glycerol) prior to 1-DE or re-swelling buffer (7 M urea, 4\% CHAPS, $2 \mathrm{M}$ thio-urea, $0.3 \%$ DTT, 2\% resolyte ampholytes $\mathrm{pH} 4-7$ ) prior to 2-DE. 


\subsection{De-glycosylation of ES proteins}

ES proteins were de-glycosylated using PNGase F (New England Biolabs) according to the manufacturer's instructions. Briefly, precipitated ES proteins were resuspended in $80 \mu \mathrm{l} 1 \mathrm{X}$ denaturation buffer (supplied with enzyme) and heated to $95^{\circ} \mathrm{C}$ for 10 mins. Following denaturation $8 \mu \mathrm{lNP}-40,8 \mu \mathrm{l} \mathrm{G} 7$ buffer (supplied with enzyme) and $5 \mu \mathrm{l}$ PNGase F were added and the samples incubated at $37^{\circ} \mathrm{C}$ overnight. The control sample was identical except for the omission of PNGase F. The ES proteins were then precipitated as above and resuspended in an appropriate buffer for electrophoresis.

\subsection{1-D and 2-D electrophoresis}

ES protein samples were analysed by 1-DE using NuPage ${ }^{\circledR}$ Novex ${ }^{\circledR} 4-12 \%$ BisTris gels (Invitrogen) and NuPage ${ }^{\circledR}$ LDS sample buffer plus Sample Reducing Agent (Invitrogen) were added to the samples prior to electrophoresis. 1-DE analysis was also used to equalise ES protein samples prior to 2-DE. For 2-DE, the ES protein samples were loaded onto pH 4-7 IPG strips (Amersham Biosciences) for separation in the first dimension. The samples were re-hydrated overnight at room temperature followed by step voltage focussing $(0.01 \mathrm{~h} 200 \mathrm{~V}$; $1.5 \mathrm{~h} 3500 \mathrm{~V} ; 1.05 \mathrm{~h} 3500 \mathrm{~V}$ ) at $22^{\circ} \mathrm{C}$ and the strips were incubated in $7 \mathrm{mls}$ of equilibrating buffer (50 mM Tris, $6 \mathrm{M} \mathrm{Urea,} \mathrm{30 \%} \mathrm{glycerol,} \mathrm{2 \%} \mathrm{SDS)} \mathrm{containing}$ $10 \mathrm{mg} \mathrm{ml}^{-1}$ DTT for $30 \mathrm{~min}$. Following this, a further equilibration step was performed with equilibrating buffer containing $25 \mathrm{mg} \mathrm{ml}^{-1}$ iodoacetamide for 30 min. For separation in the second dimension, the IPG strips were laid on 10-15\% 
non-linear gradient polyacrylamide gels and run at $75 \mathrm{~V}$ for $1 \mathrm{~h}$ and then at $150 \mathrm{~V}$ until 140 volt-hours were reached. After separation, proteins were visualised by staining with Colloidal Coomassie Blue G250 (Sigma) as described elsewhere [24].

\subsection{Immunoblotting}

ES proteins separated by 1-DE and 2-DE were transferred to Hybond-C pure nitrocellulose membranes (Amersham Biosciences) using a Novex XCell Surelock $^{\mathrm{TM}}$ Mini-Cell blot module apparatus (Invitrogen) for $1 \mathrm{~h}$ at $30 \mathrm{~V}$. Following transfer, the membranes were incubated in blocking solution (TSBT: $20 \mathrm{mM}$ Tris-HCl, $150 \mathrm{mM} \mathrm{NaCl}, 1 \%$ Tween-20, $\mathrm{pH}$ 7.6) containing 5\% skimmed milk for $3 \mathrm{~h}$ at room temperature. Primary antibody $(\mathrm{mAb} 18 \mathrm{H})$ was diluted 1:1500 in TBST containing 1\% skimmed milk and applied to the membranes overnight at $4^{\circ} \mathrm{C}$. After washing in TBST (4 X $10 \mathrm{~min}$ ), the anti-mouse-IgG secondary antibody conjugated to alkaline phosphatase (Sigma) was applied at a dilution of 1:10000 in TBST for $1 \mathrm{~h}$. The blots were developed using 5-bromo-4chloro-3-indolyl phosphate / nitro blue tetrazolium substrate (Sigma).

\subsection{Mass Spectrometry}

MALDI-TOF-MS was performed at the University of Aberdeen Promteome Facility using a protocol adapted from a published method [25]. Briefly, protein spots were excised from the stained 2-D gels and subjected to in-gel proteolytic digestion with trypsin (Sigma) using an Investigator ${ }^{\mathrm{TM}}$ ProGest $^{\mathrm{TM}}$ instrument 
(Genomic Solutions). The resulting tryptic fragments were guanidylated with methylisourea, desalted and concentrated using an Investigator ${ }^{\mathrm{TM}}$ ProMS $^{\mathrm{TM}}$ instrument (Genomic Solutions) before analysis using a PerSpective Biosystems Voyager-DE STR MALDI-TOF mass spectrometer, operating in reflectron mode at $20 \mathrm{kV}$ accelerating voltage. Spectra were internally calibrated using trypsin autodigestion products. LC-MS/MS was performed at the Sir Henry Wellcome Functional Genomics Facility, University of Glasgow. After in-gel tryptic digestion, the resulting peptides were solubilized in $0.5 \%$ formic acid and fractionated by nanoflow HPLC on a C18 reverse phase column, eluting with a continuous linear gradient to $40 \%$ acetonitrile over 20 minutes. The eluate was analysed by online electrospray tandem MS using a Qstar Pulsar instrument (Applied Biosystems). A 3-second survey scan preceded each MS/MS data collection cycle of four 3-second product ion scans, giving a duty cycle of 15 seconds. For tandem MS performed by the FingerPrints Proteomics Facility, University of Dundee, tryptic peptides were analysed on an Applied Biosystems 4700 Proteomics Analyser (MALDI-TOF-TOF-MS-MS system) in MS reflector mode to generate a peptide mass fingerprint (PMF). Five of the most intense peptide ions were selected for further analysis by MS/MS. The MS and MS/MS data were combined and used by the Applied Biosystems GPS system (Global Proteomics Server) and MASCOT (Matrix Science) to search the databases. 


\subsection{Database searching}

The PMF profiles obtained from MALDI-TOF-MS were used to search databases, run locally using MS-Fit (Protein Prospector) against a custom-made Trichinella EST database and the NemaCluster database for Trichinella [26]. The following parameters were used: methionine oxidation, cysteine carbamidomethylation and lysine guanidylation. The peptide mass tolerance was initially set at $50 \mathrm{ppm}$ but was increased to $150 \mathrm{ppm}$ when searching EST databases. Similarly, up to 3 missed cleavages were allowed when searching EST databases. Searches were also carried out against all mouse sequences in the NCBInr database in order to identify potential host proteins. Database searches using LC-MS/MS data were carried out using MASCOT (Matrix Science).

\section{Results}

\subsection{2-DE analysis of Trichinella ES proteins}

ES proteins secreted by isolated $T$. spiralis muscle larvae during in vitro cultivation were precipitated from culture supernatants collected following 6 h, 20 $\mathrm{h}$ and $40 \mathrm{~h}$ incubation in RPMI medium and analysed by 2-DE (Fig. 1A-C). The most prominent ES proteins in the $6 \mathrm{~h}$ sample migrated in the $40-60 \mathrm{kDa}$ range. These corresponded to the major glycosylated proteins in the $40 \mathrm{~h}$ ES sample as shown by Western blotting and immuno-analysis with mAb $18 \mathrm{H}$, a monoclonal antibody that is specific for tyvelose-containing glycans epitopes [27] found on some Trichinella ES proteins (Fig 1D). This was consistent with previous observations that the major immuno-dominant ES proteins of the T. spiralis 
muscle larva are glycosylated and in this size range [28, 29, 30]. Following later cultivation times, both the number of protein spots and the overall complexity of the ES profile increased, notably in the lower molecular mass range (ie 15-40 $\mathrm{kDa}$ ). The 2-DE profiles shown are representative of $T$. spiralis ES proteins and gel-to-gel reproducibility was very high between independent samples (for example, compare Fig. 1C and Fig. 2).

\subsection{Identification of Proteins by 2-DE and Mass Spectrometry}

Using the current sample preparation method and $\mathrm{pH}$ range, approximately 125 Coomassie Blue-stained spots were visible on 2-D gels of $T$. spiralis $40 \mathrm{~h}$ ES proteins (Fig. 1C). In order to identify the major ES proteins, a total of 52 different prominent spots were excised from 2-D gels (Fig 2) and a proteomic analysis of selected spots was carried out using MALDI-TOF-MS. The resulting PMF data were used to search databases. As relatively few Trichinella sequences are available in the public cDNA and protein databases, searches using these were largely unsuccessful. Consequently, a custom-made database was compiled from all Trichinella sequences, both cDNA and EST, deposited in GenBank. Latterly, the Trichinella EST cluster database compiled as part of the Parasitic Nematode EST project [26] was also used for searches. In line with other studies, a match to

a Trichinella protein was considered significant where there were at least 5 matched peptides and $15 \%$ coverage of the protein sequence [31]. For matches to ESTs, fewer peptide matches and a lower percent coverage were tolerated in making a putative assignment of protein identity. Other criteria used to assign 
spots to proteins included matching the calculated theoretical molecular mass and pI values of the protein, where possible, with the observed position of the peptide on the 2-D gel. Because of the limited availability of complete cDNA sequence data all of the spot identifications initially assigned on the basis of PMF data were considered tentative until confirmation could be obtained by tandem MS. To do this LC-MS/MS was used to supplement the PMF data and to assign identities to those proteins un-identified by MALDI-TOF alone. In these cases, searches were carried out using MASCOT (MatrixScience) and MOWSE scores $>70$ were considered to be significant.

Using the above criteria for PMF data, positive matches to Trichinella proteins or ESTs were obtained for 23 peptide spots (Table 1), although in 2 cases (spots 8 and 10) the PMF-based assignment was considered borderline. The identities of 22 were confirmed by LC-MS/MS; spot 12 was excluded as the identification based on the PMF data was to a complete cDNA and was considered robust. A further 20 spots were successfully identified using LC-MS/MS alone giving a total of 43 out of 52 Trichinella ES proteins identified using MS. The remaining 9 spots were un-matched to any Trichinella sequence currently in the database.

The 43 significant matches corresponded to only 13 different proteins encoded by Trichinella cDNAs or ESTs; 4 to known T. spiralis ES proteins, 3 to predicted ES proteins and the remaining 6 to putative proteins encoded by novel ESTs (Table 1). Twelve spots $(1,8-12,26$ and $31-35)$, ranging in size from 44.5 to $69.0 \mathrm{kDa}$ 
and with pI values ranging from 5.14 - 6.64, were assigned to a cDNA encoding the $T$. spiralis serine protease, TspSP-1 $[32,17]$. The predicted size of TspSP-1 based on the cDNA is $48 \mathrm{kDa}$, however, anti-TspSP-1 antibodies detect native proteins of 50,64 and $70 \mathrm{kDa}$ by 1-DE and evidence from de novo amino acid sequencing and tandem MS, suggests that several isoforms of the protein are present in the ES [17]. Two spots ( 2 and 7$)$ were identified as the major secreted glycoprotein $\mathrm{p} 43$; the identification of two isoforms of this protein differing in $\mathrm{pI}$ was again consistent with previous observations [29]. A further three spots $(5,27$ and 28) were identified as the secreted $45 \mathrm{kDa}$ antigen and one spot (13) was assigned to the secreted 5'-nucleotidase $[16,33]$. In these cases, there was close agreement between the predicted molecular mass and $\mathrm{pI}$ with those observed by 2 DE.

Spots assigned to three different hypothetical Trichinella proteins were also identified, confirming that these proteins are expressed and secreted. Seven spots (3 and 16-21) were assigned to ORF 9.10. Spots 3 and 16 shared molecular mass and $\mathrm{pI}$ values of $48.5 \mathrm{kDa}$ and 4.94 / 4.86, respectively, whilst the other ORF 9.10 spots formed a distinct group of lower molecular mass $(\sim 35 \mathrm{kDa})$ with pI values in the range of $4.94-5.78$. Five spots (39-43) with approximate molecular mass of $22.5-24.6 \mathrm{kDa}$ and $\mathrm{pI}$ values ranging from $4.92-6.39$ were identified as the ORF 17.20 protein. In addition, spot 46 was assigned to the ORF 11.30 protein. All of these are novel proteins that have yet to be characterised. The remaining twelve spots were assigned to proteins encoded by Trichinella ESTs, all of which 
appeared to be novel. Spots 45 and 49-52 were assigned to two related ESTs (BG353021 and BG353717), which were subsequently found on contig TS01176 in the NemaGene database. A complete ORF was identified within TS01176 encoding a novel $15.7 \mathrm{kDa}$ protein with a putative $\mathrm{N}$-terminal signal peptide. The theoretical molecular mass for this protein matched that observed for this group of spots. The ESTs BG520944 (spot 6), BG520575 (spots 14 and 15), BQ540916 (spots 29 and 30) and BG345905 (spot 38) all encoded protein fragments that included an N-terminal signal peptide, as predicted by the SignalP algorithm [34]. Thus 12 of the identified proteins were predicated to be secretory proteins due the presence of an N-terminal signal peptide. The single exception was EST BQ542714 (spot 36), which encoded a protein fragment lacking the signal sequence though this could be due to the fact that the EST probably derives from a truncated cDNA lacking 5' gene sequence information.

Despite the successful identification of 43 ES proteins, a few notable exceptions were not identified including the $53 \mathrm{kDa}$ secreted glycoprotein [35] and the secreted nucleoside diphosphate kinase [15]. These proteins have predicted $\mathrm{pI}$ values of 8.42 and 7.94 respectively and therefore will not resolve on the 2-D gels used in this study.

\subsection{Glycosylation of $T$. spiralis ES proteins}


The major tyvelosylated T. spiralis ES glycoproteins resolved as approximately 30 immuno-reactive peptides following 2-DE and Western analysis with the antityvelose monoclonal Ab18H (Fig 1D). Fifteen of these tyvelose-bearing proteins were identified by MS including the secreted $45 \mathrm{kDa}$ antigen, glycoprotein $\mathrm{p} 43$ and the TspSP-1 serine protease. Following treatment with PNGase F, which cleaves $N$-linked glycans many ES proteins, including those not recognised by the $\mathrm{mAb} 18 \mathrm{H}$ antibody, changed position with regard to their molecular weight and $\mathrm{pI}$

(Fig 3). Overall, there was a net movement of spots into the $30-40 \mathrm{kDa}$ and 15 $\mathrm{kDa}$ molecular mass regions indicating that a number of peptides had decreased in mass following de-glycosylation. Therefore, a large subset of the ES proteins appears to be glycosylated with $N$-linked glycans. These included the secreted 45 $\mathrm{kDa}$ and those encoded by the ESTs BG520575, BQ540916, BG353717 and BG353021. Peptide spots that did not change their position following deglycosylation included those identified as the ORF 9.10 protein, the secreted 5'nucleotidase, the ORF 17.20 and ORF 11.30 proteins, and those spots encoded by BG354905 and BG520944.

\section{Discussion}

To date few Trichinella ES proteins have been analysed in terms of their biological activity, due largely to problems in identifying individual proteins. Yet these proteins function at the host-parasite interface and are probably crucial for successful parasitism both during the muscle stage and the intestinal stage during which a new infection is established in a host animal. In the current study, we 
have successfully used 2-DE and proteomic analysis tools to identify ES proteins from the muscle larva, despite the absence of a genome-sequencing project for Trichinella. Using PMF data from MALDI-TOF-MS and LC-MS/MS and a custom-assembled Trichinella sequence database, we assigned identities to 43 out of the 52 ES peptide spots analysed. The majority of the ES proteins identified contain a predicted $\mathrm{N}$-terminal signal peptide which supports the identifications and verifies that they are secretory proteins. The use of 2-DE, coupled with protein identification, has also been informative with regard to determining the overall constitution and complexity of the ES. The 43 peptide spots identified represented only 13 different proteins, indicating that several isoforms of many of the proteins were present. There are a number of possible explanations for the different isoforms including post-translational modification, splice variants and protein processing. For example, a large subset of T. spiralis ES proteins is glycosylated and differential glycosylation may account for some of the isoforms. The significance of differentially glycosylated variants may become more apparent once the roles of individual ES proteins have been elucidated. For instance, it has been suggested that glycosylation may influence the activity of the TspSP-1 serine protease, as several $N$-glycosylation sites are found near the active site of the protein [17].

The question of the function of the muscle larva ES proteins remains to be determined. Undoubtedly, some of these proteins will play a role in the establishment or maintenance of the nurse cell and the observations that ES 
proteins localise to the surface of the parasite [36] and to the infected host nuclei $[6,7,8]$ support this conclusion. However, tyvelose-bearing ES glycoproteins may also play a significant role in the intestinal phase. These glycoproteins originate in the muscle larva in a specialised secretory organ, the stichosome and are deposited in the intestinal epithelium during the establishment of a new infection $[37,38]$. Furthermore, antibodies raised against Tyvelose are protective and result in rapid expulsion of parasites from the intestine on administration of a challenge infection $[39,40]$. The application of proteomics in the present study has provided some much-needed basic data which will allow more focussed studies on the functions of individual Trichinella ES proteins to be carried out. These studies are in progress and will be the subject of future communications. The identification of the ES proteins is critical to understanding the host-parasite interaction and may have broader implications to the study of the fundamental biological mechanisms including those underlying maintenance of the differentiated state in mammalian cells.

\section{Acknowledgements}

We would like to thank Dr. P. Cash, E. Argo, E. Ratray and I. Davidson of the Aberdeen Proteome Facility, Dr. R. Burchmore of the Sir Henry Wellcome Functional Genomics Facility and D. Lamont and K. Beattie of the FingerPrints Proteomics Facility. We are also grateful to Dr J. Appleton for the gift of the $\mathrm{mAb} 18 \mathrm{H}$. This work was supported by a grant from the BBSRC. 


\section{References}

[1] Despommier, D. D., in: Campbell, W. C. (Ed.) Biology in Trichinella and Trichinosis, Plenum Press, New York 1983, pp. 75-151.

[2] Jasmer, D. P., J.Cell Biol. 1993, 121, 785-793.

[3] Jasmer, D. P., Bohnet, S., Prieur, D. J., Exp. Parasitol. 1991, 72, 321-331.

[4] Despommier, D., Am. J. Pathol. 1975, 78, 477-496.

[5] Leung, R. K., Ko, R. C., J. Helminthol. 1997, 71, 113-118.

[6] Lee, D. L., Ko, R. C., Yi, X. Y., Yeung, M. H., Parasitology 1991, 102, 117-123.

[7] Yao, C., Jasmer, D. P., Infect. Immun. 2001, 69, 4065-4071.

[8] Yao, C., Jasmer, D. P., Mol. Biochem. Parasitol. 1998, 92, 207-218.

[9] Mak, C. H., Ko, R. C., Parasitology 2001, 123, 301-308.

[10] Mak, C. H., Chung, Y. Y., Ko, R. C., Parasitology 2000, 120, 527-533.

[11] Mak, C. H.,Ko, R. C., Eur. J. Biochem. 1999, 260, 477-481.

[12] Lun, H. M., Mak, C. H., Ko, R. C., Parasitol. Res. 2003, 90, 27-37.

[13] Criado-Fornelio, A., Armas-Serra, C., Gimenez-Pardo, C., CasadoEscribano, N. et al., Vet. Parasitol. 1992, 45, 133-140.

[14] Arden, S. R., Smith, A. M., Booth, M. J., Tweedie, S., et al., Mol. Biochem .Parasitol. 1997, 90, 111-119.

[15] Gounaris, K., Thomas, S., Najarro, P., Selkirk, M. E., Infect.Immun. 2001, 69, 3658-3662.

[16] Gounaris, K., Infect. Immun. 2002, 70, 4917-4924.

[17] Romaris, F., North, S. J., Gagliardo, L. F., Butcher, B. A., et al., Mol. Biochem. Parasitol. 2002, 122, 149-160.

[18] Yatsuda, A. P., Krijgsveld, J., Cornelissen, A. W., Heck, A. J., de Vries, E., J. Biol. Chem. 2003, 278, 16941-16951.

[19] Jefferies, J. R., Campbell, A. M., van Rossum, A. J., Barrett, J., Brophy, P. M., Proteomics. 2001, 1, 1128-1132.

[20] Bernal, D., de la Rubia, J. E., Carrasco-Abad, A. M., Toledo, R., et al., FEBS Lett. 2004, 563, 203-206.

[21] Connolly, B., Ingram, L. J., Smith, D. F., Exp. Parasitol. 1995, 80, 488-498.

[22] Kuratli, S., Hemphill, A., Lindh, J., Smith, D. F., Connolly, B., Mol. Biochem. Parasitol. 2001, 115, 199-208.

[23] Wessel, D.Flugge, U. I., Anal. Biochem. 1984, 138, 141-143. 
[24] Anderson, N. L., Esquer-Blasco, R., Hofmann, J. P., Anderson, N. G., Electrophoresis 1991, 12, 907-930.

[25] Shevchenko, A., Wilm, M., Vorm, O., Mann, M., Anal. Chem. 1996, 68, 850-858.

[26] Wylie, T., Martin, J. C., Dante, M., Mitreva, M. D., et al., Nucleic Acids Res. 2004, 32 (Database issue), D423-D426.

[27] Reason, A. J., Ellis, L. A., Appleton, J. A., Wisnewski, N., et al., Glycobiology 1994, 4, 593-603.

[28] Denkers, E. Y., Wassom, D. L., Krco, C. J., Hayes, C. E., J. Immunol. 1990, 144, 3152-3159.

[29] Denkers, E. Y., Wassom, D. L., Hayes, C. E., Mol. Biochem. Parasitol. 1990, 41, 241-249.

[30] Wu, Z., Nagano, I., Takahashi, Y., Parasitology 1999, 118, 615-622.

[31] Cohen, A. M., Rumpel, K., Coombs, G. H., Wastling, J. M., Int. J. Parasitol. 2002, 32, 39-51.

[32] Nagano, I., Wu, Z., Nakada, T., Boonmars, T., Takahashi, Y., J. Parasitol. 2003, 89, 92-98.

[33] Gounaris, K., Selkirk, M. E., Sadeghi, S. J., Mol. Biochem. Parasitol. 2004, $136,257-264$.

[34] Bendtsen, J. D., Nielsen, H., von Heijne, G., Brunak, S., J. Mol. Biol. 2004, 340, 783-795.

[35] Zarlenga, D. S.Gamble, H. R., Mol. Biochem. Parasitol. 1990, 42, 165-174.

[36] McVay, C. S., Tsung, A., Appleton, J., Infect. Immun. 1998, 66, 1941-1945.

[37] Capo, V., Silberstein, D., Despommier, D. D., J. Parasitol. 1986, 72, 931938.

[38] ManWarren, T., Gagliardo, L., Geyer, J., McVay, C., et al., Infect. Immun. $1997,65,4806-4812$.

[39] Appleton, J. A., Schain, L. R., McGregor, D. D., Immunology 1988, 65, 487-492.

[40] Arasu, P., Ellis, L. A., Iglesias, R., Ubeira, F. M., Appleton, J. A., Mol. Biochem. Parasitol. 1994, 65, 201-211. 


\section{Figure Legends}

Figure 1. 2-DE analysis $T$. spiralis muscle larvae ES proteins in the $\mathrm{pH}$ range 3-7 and separated on 10-15\% non-linear gradient polyacrylamide gels in the second dimension. 2-D gels stained with colloidal Coomassie blue G250 of ES proteins collected after $6 \mathrm{~h}(\mathrm{~A}), 20 \mathrm{~h}(\mathrm{~B})$ or $40 \mathrm{~h}$ (C) of in vitro culture. (D) Immunoblot of 2-D gel of $40 \mathrm{~h}$ ES proteins, probed with the anti-tyvelose mAb $18 \mathrm{H}$.

Figure 2. Coomassie-stained 2-D gel of $40 \mathrm{~h}$ ES proteins showing the positions of the 52 protein spots subjected to analysis by MS. Spots were numbered and those identified are listed in Table 1.

Figure 3. Comparison of the 2-DE profiles of $40 \mathrm{~h}$ ES proteins that have been treated (+PNGase) or mock-treated (-PNGase) with PNGase F. Spots identified by MALDI-TOF-MS following de-glycosylation: (a) secreted 5'-nucleotidase; (b) ORF 9.10; (c) $45 \mathrm{kDa}$ antigen; (d) BG520575; (e) TspSp-1; (f) ORF 17.20. The ORF 17.20 peptide spots that do not change position on treatment with PNGase are marked with arrowheads. 
Figure 1
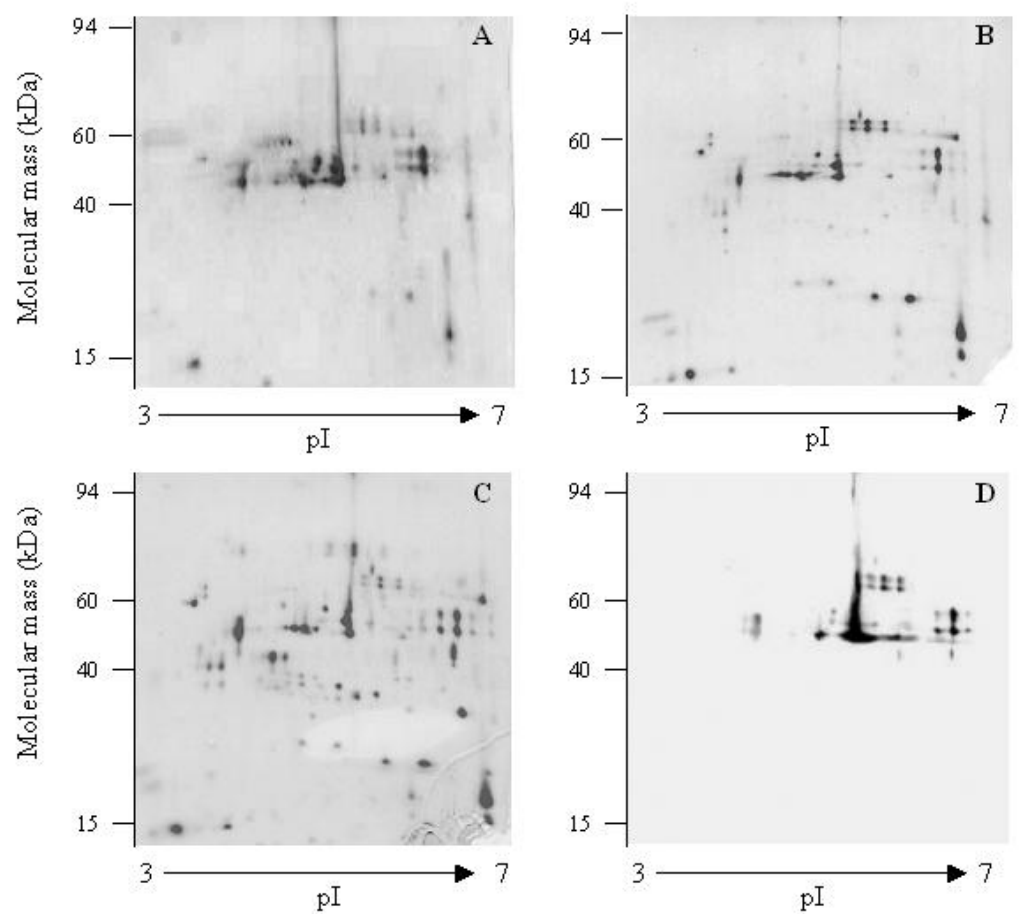
Figure 2

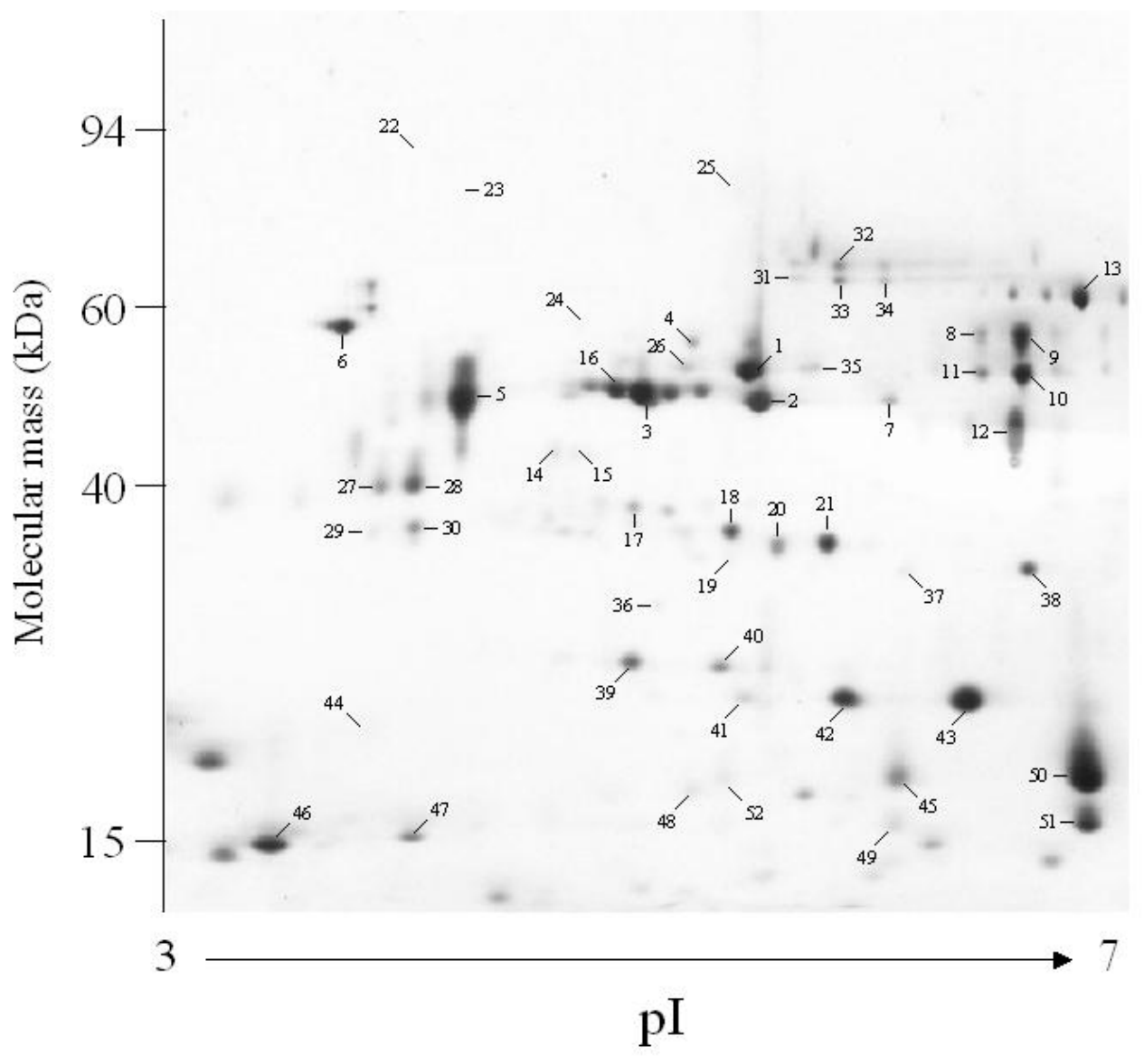


Figure 3
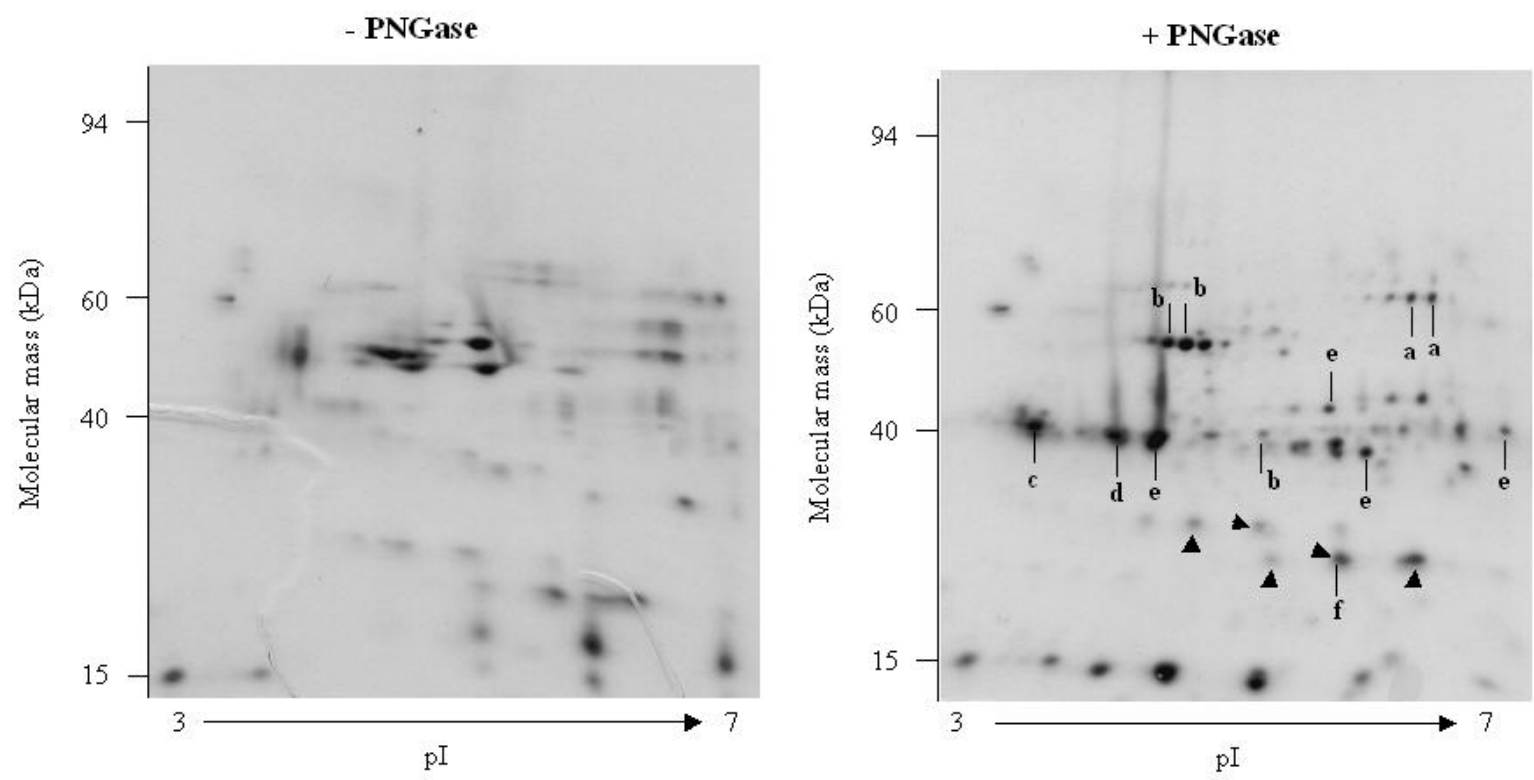
Table 1. Identification of $T$. spiralis ES proteins identified by MALDI-TOF and LC-MS/MS

\begin{tabular}{|c|c|c|c|c|c|c|c|}
\hline Spot & $\begin{array}{l}\text { Trichinella } \\
\text { Protein }\end{array}$ & $\begin{array}{l}\text { Accession } \\
\text { Number }\end{array}$ & $\begin{array}{c}\text { Theoretical } \\
\mathrm{M}_{\mathrm{r}} / \mathrm{pI}^{1}\end{array}$ & $\begin{array}{l}\text { Observed } \\
\mathrm{M}_{\mathrm{r}} / \mathrm{pI}\end{array}$ & $\begin{array}{c}\text { Coverage } \\
(\%)\end{array}$ & $\begin{array}{l}\text { Matched } \\
\text { Peptides }\end{array}$ & $\begin{array}{c}\text { MOWSE } \\
\text { Score }^{2}\end{array}$ \\
\hline 1 & Serine protease & AY02897 & $48.0 / 6.33$ & $54.0 / 5.44$ & 24 & 4 & 274 \\
\hline 2 & gp43 & M95499 & $38.0 / 5.95$ & $47.1 / 5.48$ & 25 & 7 & 433 \\
\hline 3 & ORF 9.10 & U88241 & $47.6 / 5.60$ & $48.5 / 4.94$ & & & 440 \\
\hline 5 & $45 \mathrm{kDa}$ antigen & U01847 & $31.0 / 4.76$ & $47.1 / 4.21$ & 17 & 5 & 326 \\
\hline 6 & Unknown & BG520944 & & $57.0 / 3.75$ & & & 362 \\
\hline 7 & gp43 & M95499 & $38.0 / 5.95$ & $47.1 / 6.04$ & 13 & 5 & 270 \\
\hline 8 & Serine protease & AY02897 & $48.0 / 6.33$ & $55.8 / 6.44$ & 7 & 3 & 121 \\
\hline 9 & Serine protease & AY02897 & $48.0 / 6.33$ & $55.8 / 6.64$ & & & 175 \\
\hline 10 & Serine protease & AY02897 & $48.0 / 6.33$ & $51.0 / 6.64$ & 12 & 4 & 214 \\
\hline 11 & Serine protease & AY02897 & $48.0 / 6.33$ & $51.0 / 6.44$ & & & 244 \\
\hline 12 & Serine protease & AY02897 & $48.0 / 6.33$ & $44.5 / 6.58$ & 42 & 7 & ND \\
\hline 13 & 5'-nucleotidase & AY 12757 & $62.0 / 6.13$ & $62.8 / 6.86$ & 15 & 6 & 1117 \\
\hline 14 & Unknown & BG520575 & & $41.5 / 4.60$ & 24 & 6 & 218 \\
\hline 15 & Unknown & BG520575 & & $41.5 / 4.69$ & 25 & 10 & 263 \\
\hline 16 & ORF 9.10 & U88241 & $47.6 / 5.60$ & $48.5 / 4.86$ & 32 & 10 & 404 \\
\hline 17 & ORF 9.10 & U88241 & $47.6 / 5.60$ & $36.4 / 4.94$ & 38 & 5 & 392 \\
\hline 18 & ORF 9.10 & U88241 & $47.6 / 5.60$ & $35.0 / 5.36$ & & & 423 \\
\hline 19 & ORF 9.10 & U88241 & $47.6 / 5.60$ & $32.5 / 5.36$ & 21 & 5 & 405 \\
\hline 20 & ORF 9.10 & U88241 & $47.6 / 5.60$ & $33.2 / 5.55$ & 35 & 5 & 336 \\
\hline 21 & ORF 9.10 & U88241 & $47.6 / 5.60$ & $33.2 / 5.78$ & 35 & 6 & 543 \\
\hline 26 & Serine protease & AY02897 & $48.0 / 6.33$ & $54.0 / 5.14$ & & & 163 \\
\hline 27 & $45 \mathrm{kDa}$ antigen & U01847 & $31.0 / 4.76$ & $38.0 / 3.92$ & & & 87 \\
\hline 28 & $45 \mathrm{kDa}$ antigen & U01847 & $31.0 / 4.76$ & $38.0 / 4.00$ & 14 & 6 & 106 \\
\hline 29 & Unknown & BQ540916 & & $35.0 / 3.89$ & 22 & 5 & 496 \\
\hline 30 & Unknown & BQ540916 & & $35.0 / 4.00$ & 27 & 6 & 417 \\
\hline 31 & Serine protease & AY02897 & $48.0 / 6.33$ & $65.0 / 5.64$ & & & 175 \\
\hline 32 & Serine protease & AY02897 & $48.0 / 6.33$ & $69.0 / 5.83$ & & & 210 \\
\hline 33 & Serine protease & AY02897 & $48.0 / 6.33$ & $65.0 / 5.83$ & & & 211 \\
\hline 34 & Serine protease & AY02897 & $48.0 / 6.33$ & $65.0 / 6.01$ & & & 201 \\
\hline 35 & Serine protease & AY02897 & $48.0 / 6.33$ & $47.1 / 5.69$ & & & 105 \\
\hline 36 & Unknown & BQ542714 & & $28.2 / 5.00$ & & & 239 \\
\hline 38 & Unknown & BG354905 & & $31.0 / 6.67$ & & & 214 \\
\hline 39 & ORF 17.20 & U88239 & $19.5 / 6.13$ & $24.6 / 4.92$ & & & 211 \\
\hline 40 & ORF 17.20 & U88239 & $19.5 / 6.13$ & $24.6 / 5.33$ & 47 & 9 & 338 \\
\hline 41 & ORF 17.20 & U88239 & $19.5 / 6.13$ & $22.5 / 5.42$ & & & 179 \\
\hline 42 & ORF 17.20 & U88239 & $19.5 / 6.13$ & $22.5 / 5.89$ & 40 & 16 & 208 \\
\hline 43 & ORF 17.20 & U88239 & $19.5 / 6.13$ & $22.5 / 6.39$ & 37 & 9 & 320 \\
\hline 45 & Unknown & BG353021 & $15.7 / 6.28^{3}$ & $18.2 / 6.10$ & & & 256 \\
\hline 46 & ORF 11.30 & U88238 & $12.7 / 4.17$ & $15.0 / 3.44$ & & & 397 \\
\hline 49 & Unknown & BG353021 & $15.7 / 6.28^{3}$ & $16.0 / 6.06$ & & & 257 \\
\hline 50 & Unknown & BG353021 & $15.7 / 6.28^{3}$ & $18.2 / 6.89$ & 57 & 7 & 387 \\
\hline 51 & Unknown & BG353717 & $15.7 / 6.28^{3}$ & $16.3 / 6.89$ & 39 & 6 & 239 \\
\hline 52 & Unknown & BG353021 & $15.7 / 6.28^{3}$ & $18.2 / 5.36$ & & & 310 \\
\hline
\end{tabular}

\footnotetext{
${ }^{1}$ Theoretical molecular mass $(\mathrm{kDa})$ and $\mathrm{pI}$

${ }^{2}$ A MOWSE score of $>70$ was used to assign identity to a protein analysed by LC-MS/MS

${ }^{3}$ Molecular mass and pI of predicted protein encoded on contig TS 01176
} 